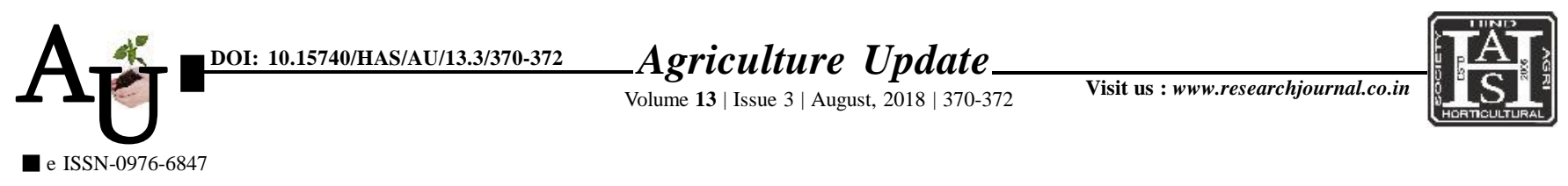

\title{
Research Article: Farmers perception towards crop insurance as a risk management tool
}

Rajeshwari M. Bhoyar, V.V. Gohad and G.S. Chachere

Article Chronicle :

Received :

26.05.2018;

Revised :

09.07.2018;

Accepted :

25.07.2018

KEY WoRdS :

Perception, Crop

insurance, Risk

management

strategies
SUMMARY : The present study on farmers perception towards crop insurance as a risk management tool was conducted in the year 2017-18 in the Amravati district. For the study 80 respondents were purposively selected from two tehsils of district with the help of random sampling method. Frequencies, mean, standard deviation, correlation of co-efficient analysis were employed for interpreting the results. The study revealed that age, farming experience and awareness are positively and significantly correlated with perception at 0.01 level of probability. And education, extension contact and source of information are positively and significantly correlated with perception at 0.05 level of probability and annual income and land holding are negatively non-significant with perception. Social participation has found non-significant relationship with perception.

How to cite this article : Bhoyar, Rajeshwari M., Gohad, V. V. and Chachere, G.S. (2018). Farmers perception towards crop insurance as a risk management tool. Agric. Update, 13(3): 370-372; DOI : 10.15740/HAS/AU/ 13.3/370-372. Copyright@2018: Hind Agri-Horticultural Society.
Author for correspondence :

\section{V.V. Gohad}

Department of

Extension Education, Shri Shivaji Agriculture

College, Amravati (M.S.)

India

Email : vinay.gohad@

rediffmail.com

See end of the article for

authors' affiliations 